Published September 2018

Jurnal Rekayasa Material, Manufaktur dan Energi

http://jurnal.umsu.ac.id/index.php/RMME

\title{
Pengaruh Proses Equal Channel Angular Pressing Terhadap Sifat Mekanik Aluminium Silikon Dengan Suhu Anil $300^{\circ} \mathrm{C}$
}

\author{
Doni Eka Phutra Damanik dan Yulfitra ${ }^{*}$ \\ Jurusan Teknik Mesin, Fakultas Teknologi Industri, Institut Teknologi Medan \\ Jl. Gedung Arca No. 52, Medan. Indonesia \\ *Email: yulfitra@itm.ac.id
}

\begin{abstract}
ABSTRAK
Penelitian ini bertujuan untuk mempelajari pengaruh proses Equal Channel Angular Pressing terhadap sifat mekanik aluminium silikon dengan suhu anil $300^{\circ} \mathrm{C}$. Batang aluminium silikon dengan ukuran panjang $40 \mathrm{~mm}$ dan lebar diameter 9,5 mm dilewatkan pada cetakan ECAP dengan sudut alur cetakan $120^{\circ}$. Kekerasan bahan dan struktur mikro bahan sebelum dan sesudah proses ECAP diperiksa dan dibandingkan . Hasilnya menunjukkan bahwa setelah proses ECAP, kekerasan aluminium silikon pada penampang memanjang meningkat dan cukup merata yaitu pada waktu tahan anil 10 menit nilai kekerasannya 54,30 BHN, pada waktu tahan 15 menit nilai kekerasannya naik menjadi 55,08 BHN dan pada waktu tahan 25 menit nilai kekerasannya naik menjadi 55,69 BHN, begitu juga pada struktur mikronyamenunjukkan bahwa semakin lama waktu tahan anil, maka semakin halus butir-butir pada aluminium silikon.
\end{abstract}

Kata Kunci : Aluminium silikon, ECAP, kekerasan, metallografi.

Effect of Equal Channel Angular Pressing Process on the Mechanical Properties of Aluminum Silicon with Annealing Temperature $300^{\circ} \mathrm{C}$

\begin{abstract}
The aim of this study to study the effect of the Equal Channel Angular Pressing process the mechanical properties of aluminum silicon with annealing temperature of $300{ }^{\circ} \mathrm{C}$. An aluminum silicon rod with a length of $40 \mathrm{~mm}$ and a width of $9.5 \mathrm{~mm}$ in diameter is passed to the ECAP mold with a mold flow angle of $120^{\circ}$. Material hardness and microstructure of materials before and after the ECAP process are examined and compared. The results showed that after the ECAP process, the hardness of aluminum silicon in the longitudinal section increased and was fairly evenly distributed, ie, at annealing time of 10 minutes the hardness value was $54.30 \mathrm{BHN}$, at 15 minutes resistance the hardness increased to 55.08 BHN and 25 minutes the hardness value rose to $55.69 \mathrm{BHN}$, as well as the microstructure showed that the longer the time annealed, the finer the grains on silicon aluminum.
\end{abstract}

Keywords: Aluminum silicon, ECAP, hardness, metallography.

Copyright $^{\circledR} 2018$ Jurnal Rekayasa Material, Manufaktur dan Energi. This is an open acces article under the CC-BY-SA lisence (https://creativecommons.org/licenses/by-sa/4.0/). 


\section{Published September 2018 \\ Jurnal Rekayasa Material, Manufaktur dan Energi http://jurnal.umsu.ac.id/index.php/RMME}

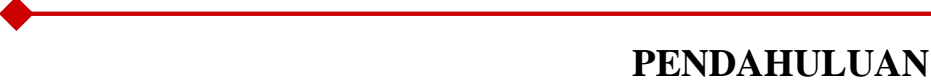

Seiring dengan perkembangan jaman yang sedemikian pesat dewasa ini, menuntut adanya material yang berukuran tinggi, mampu bentuk yang tinggi, tahan korosi dan komposisi kimia yang sederhana [1]. Pemilihan bermacam-macam ragam bahan atau material logam yang biasa dipergunakan sebagai bahan industri menjadi fenomena didalam proses produksi. Pada berbagai aplikasi, material-material kini harus dapat beradaptasi dengan permintaan konsumen yang semakin tinggi. Material logam, contohnya, dituntut untuk memiliki kekuatan yang besar namun juga harus memiliki keuletan dan ketangguhan yang tinggi.

Untuk memenuhi tuntutan jaman, bermacam penelitian dilakukan untuk mendapatkan sifat mekanik material logam yang lebih baik. Beberapa proses seperti penghalusan butir yaitu proses yang di lakukan untuk merubah logam yang berukuran kasar menjadi material dengan butir yang sangat halus. Selain itu salah satu usaha peningkatan sifat mekanik juga dilakukan dengan cara superplastisitas material. Superplastisitas adalah proses difusi terkontrol yang terjadi pada temperatur tinggi dalam material dimana ukuran butir mencapai 1-10 $\mu \mathrm{m}$ [2].

Secara mikrostruktur, logam tersusun dari butir-butir logam yang memiliki orientasi tertentu. Antara butir yang satu dengan butir yang lain dibatasi oleh batas butir ( grain boundary ). Butir (grain) adalah sekumpulan partikel-partikel logam yang memiliki orientasi kristal yang sama. Makin banyak partikel-partikel yang terkumpul pada suatu lokasi dengan arah orientasi kristal yang sama maka makin besarlah butir tersebut [2].

Batas butir merupakan bidang yang membatasi antara partikel-partikel logam yang berbeda orientasinya. Butir yang memiliki diameter sampai 10 mikron disebut butir halus. Diameter butir sampai 50 mikron disebut butir sedang dan lebih dari 50 mikron biasanya disebut butir kasar [3].

Butir yang halus dan homogen pada suatu material mempengaruhi sifat mekanisnya seperti untuk mendapatkan yield strength yang tinggi, meningkatkan ketangguhan dan keuletan material dengan meningkatkan laju regangannya (strain rate). Semakin banyak batas butir, energi yang diperlukan untuk melewatinya akan semakin besar sehingga dibutuhkan lebih banyak tenaga untuk mendeformasi material tersebut, atau dengan kata lain material tersebut semakin keras.

Sudah banyak penelitian yang dilakukan untuk mendapatkan butir hingga ukuran dibawah $1 \mu \mathrm{m}$ (nano grain) untuk bisa terbentuknya butir yang sangat halus pada material. Proses yang dilakukan untuk mendapatkan butir yang sangat halus biasa dilakukan dengan proses severe plastic deformation (SPD). SPD adalah metode yang digunakan untuk merubah logam dengan butir yang kasar menjadi material dengan butir yang sangat halus. Selain untuk mendapatkan logam dengan butir yang sangat halus, SPD juga memperbaiki sifat mekanik dan fisik material sehingga dapat digunakan untuk banyak aplikasi [2].

Ada beberapa keuntungan dalam metode SPD, yaitu:

a. Dapat mempertahankan kehalusan dan keseragaman butir. Hal ini menjadi masalah jika menerapkan proses dengan cara konvensional.

b. Porositas yang rendah.

c. Tidak menyebabkan kerusakan mekanik atau crackterhadap sampel.

d. Dapat digunakan untuk memproses sampel dengan volume yang besar.. 


\section{Published September 2018 \\ Jurnal Rekayasa Material, Manufaktur dan Energi http://jurnal.umsu.ac.id/index.php/RMME}

Ada beberapa teknik SPD yang telah dikembangkan. Teknik SPD yang tertua dan terpopuler adalah Equal Channel Angular Pressing (ECAP), ada juga High Pressure Torsion (HPT), dan Accumulatible Roll Bonding (ARB) [2].

1. Equal Channel Angular Pressing(ECAP), Sampel ditekan dengan menggunakan mesin press melewati die yang terdiri dari dua pipa membentuk sudut hampir $90^{\circ}$.

2. High Pressure Torsion(HPT), material ditahan di suatu landasan atau alas dan di strain dengan beban torsi dibawah tekanan $(\mathrm{P})$ beberapa Gpa. Efisiensi dari proses ini dipengaruhi oleh berapa kali rotasi $(\mathrm{N})$ yang dilakukan.

3. Accumulatible Roll Bonding(ARB), Untuk menghasilkan logam berkekuatan tinggi proses ARB memerlukan pengulangan tekanan rolling sampai puluhan kali.

Pada penelitian kali ini, SPD akan dilakukan menggunakan teknik ECAP. Dipilih dengan proses ECAP karena dianggap lebih sederhana dibandingkan dengan proses HPT dan ARB. Temperatur anil yang digunakan pra proses ECAP yaitu $300^{\circ} \mathrm{C}$,dengan waktu tahan pada proses anil 10 menit, 15 menit, 25 menit. Dengan ECAP, material akan mengalami penghalusan butir dengan cara memasukan sampel pada dies dan diberi penekanan. Namun, sebelum di ECAP material akan terlebih dulu mengalami perlakuan panas anil.

\section{Perumusan Masalah}

Penelitian ini dilakukan untuk mengetahui proses yang paling efektif untuk mendapatkan butir yang halus dan cara meningkatkan butir hingga berukuran halus, pada material aluminium AlSi 1. Proses yang dilakukan pada penelitian ini adalah pemanasan anil kemudian pengujiankekerasan dan pengamatan mikrostruktur butir. Setelah melakukan anil kemudian akan dilakukan proses SPD menggunakan teknik ECAP pada sudut $120^{\circ}$. Secara khusus akan dilakukan pengujiankekerasan dan pengamatan mikrostruktur. Dari percobaan tersebut akan diamati perubahan mikrostrukturnya, ukuran butir, dan kekuatan mikronya. Berdasarkan studi pada banyak jurnal-jurnal penelitian yang telah ada belum ditemukan bagaimana cara meningkatkan butir berukuran halus dari suatu material, hanya menjelaskan cara mendapatkan butir berukuran halus.

\section{Batasan Masalah}

Dalam suatu batasan masalah ini Parameter yang akan di analisa dalam penelitian ini adalah hanya pada analisa untuk melihat pengaruh proses anil dan proses ECAP pada aluminium silikon dengan membandingkan spesimen sebelum dan sesudah dianil serta diECAP terhadap kekerasan dan struktur mikronya.

\section{Tujuan Penelitian}

Tujuan Umum

Secara umum, tujuan penelitian ini adalah menganalisa penghalusan butir pada aluminium silikon dengan teknik Equal Channel Angular Pressing dengan sudut $120^{\circ}$.

\section{Tujuan Khusus}

Secara khusus, tujuan dilakukannya penelitian ini adalah:

1. Mempelajari pengaruh proses anil dan proses ECAP terhadap kekerasan dan struktur mikronya sebelum di anil.

2. Mempelajari pengaruh proses anil dan proses ECAP terhadap kekerasan dan struktur mikronya sesudah di anil. 
ISSN 2622-7398 (online)

Jurnal Rekayasa Material, Manufaktur dan Energi, Vol. 1, No. 1, September 2018, 30-38

DOI:https://doi.org/10.30596/rmme.v1i1.2433

Published September 2018

\section{Jurnal Rekayasa Material, Manufaktur dan Energi http://jurnal.umsu.ac.id/index.php/RMME}

\section{METODOLOGI PENELITIAN}

Kegiatan penelitian ini dilakukan dibeberapa tempat, yaitu:

1. Toko Panca Djaya (Pemesanan Benda Uji)

2. Workshop Fakultas Teknik Universitas Negeri Medan (Uji Komposisi)

3. Laboratorium Teknologi Mekanik Universitas Sumatera Utara (Penelitian dan Proses

Pembubutan)

4. Institut Teknologi Medan (Penyusunan Laporan Tugas Akhir)

\section{Diagram Alir}

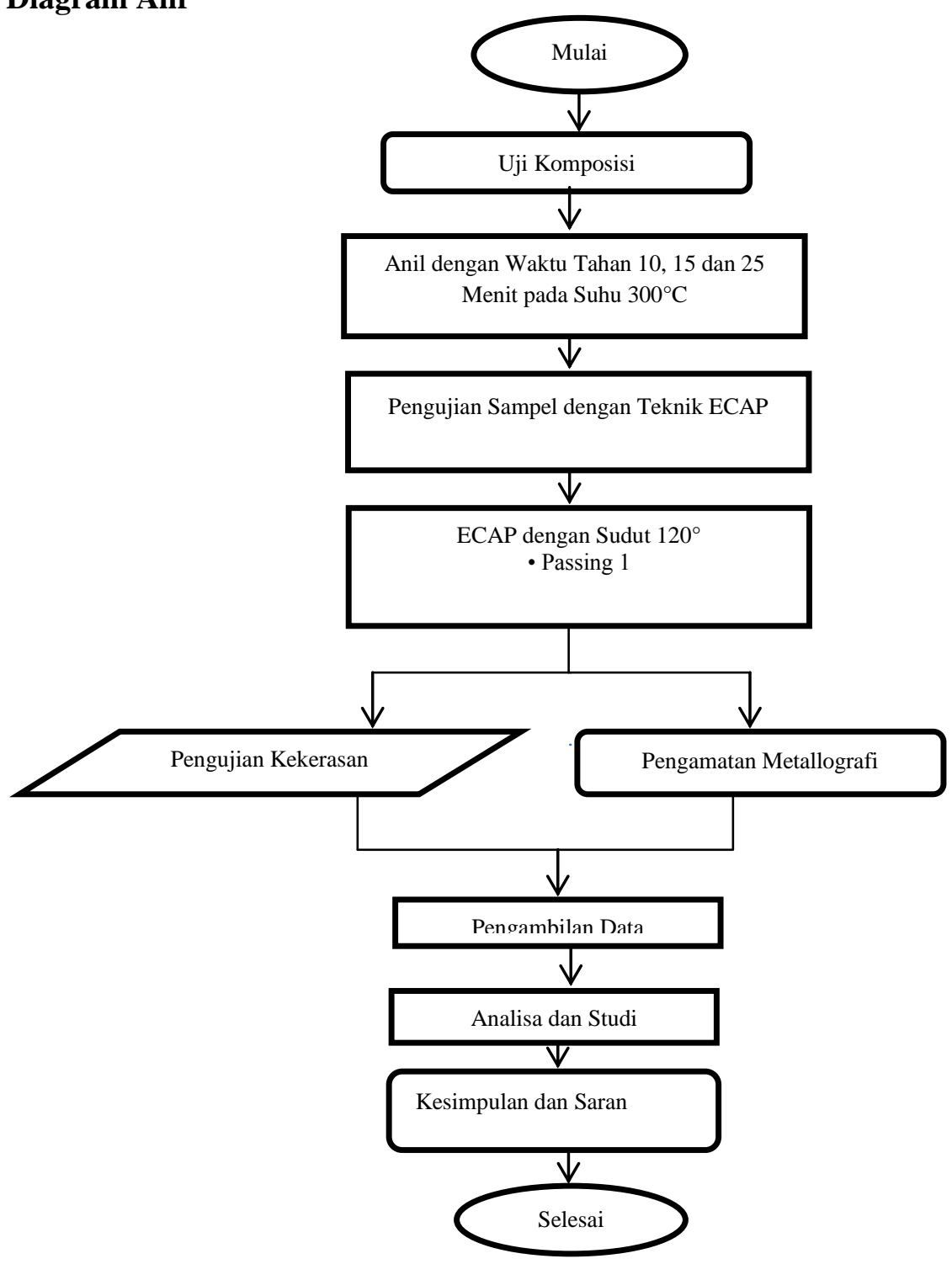

Gambar 1. Digram alir

Copyright $^{\circledR} 2018$ Jurnal Rekayasa Material, Manufaktur dan Energi. This is an open acces article under the CC-BY-SA lisence (https://creativecommons.org/licenses/by-sa/4.0/). 


\section{Jurnal Rekayasa Material, Manufaktur dan Energi http://jurnal.umsu.ac.id/index.php/RMME}

\section{HASIL DAN PEMBAHASAN}

Dalam bab ini akan dibahas hasil-hasil yang diperoleh selama pelaksanaan penelitian, yang meliputi proses ECAP dengan variabel temperatur $300^{\circ} \mathrm{C}$ dengan waktu tahan anil 10,15 dan 25 menitbeserta pengaruh ECAP terkait dengan kekerasan mikro dan pengamatan mikrostruktur.

\section{Hasil Spesimen dari Proses ECAP}

Hasil dari spesimen aluminium dapat dilihat pada gambar 2 berikut ini :

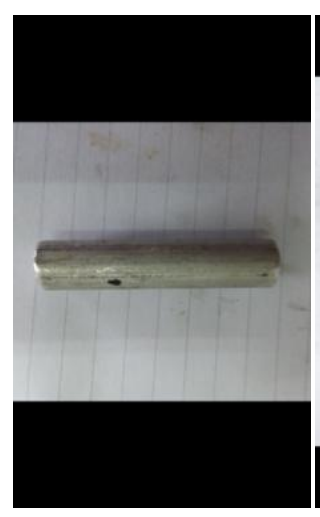

a

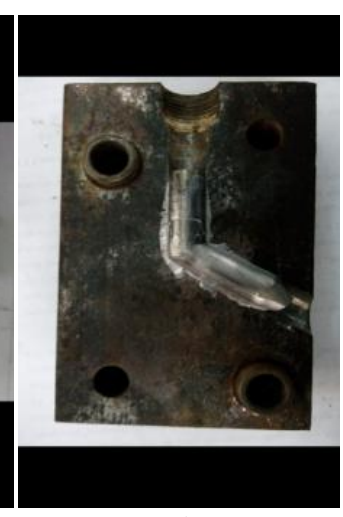

b

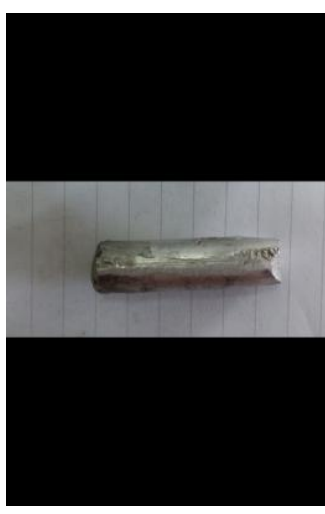

c

Gambar 2.(a) Spesimen sebelum di ECAP, (b) Proses spesimen setelah melewati sudut lengkukan pada dies ketika di ECAP(c) Spesimen yang sudah di ECAP.

Berdasarkan pengamatan hasil ECAP pada gambar 2 menunjukkan bahwa spesimen mengalami penghalusan butir, terlihat pada spesimen yang sudah melewati sudut dies ketika di ECAP dikarenakan penekanan paksa hingga spesimen melewati sudut dies (gambar 2. b), begitu juga untuk spesimen yang sudah di ECAP, butir terlihat lebih halus secara kasat mata dan spesimen mengalami pertambahan diameter dan pengurangan panjang spesimen. Proses pengujian ECAP dilakukan secara manual menggunakan mesin tekan hidrolik yang berkapasitas 10 ton dengan 1 kali passing. Ketika dilakukan dengan 1 kali passing dengan proses ECAP terjadi penambahan diameter yaitu $0,5 \mathrm{~mm}$ pada spesimen dikarenakan toleransi spesimen pada diesnya, dan terjadi pengurangan panjang pada spesimen yaitu dari panjang $40 \mathrm{~mm}$ menjadi $34 \mathrm{~mm}$. Proses ECAP dilakukan menggunakan pelumas bedak baby powder, pelumasan dilakukan untuk mengurangi gesekan dan memudahkan masuk sampel dengan toleransi ukuran dies yang rendah.

\section{Hasil Pengujian}

Hasil pengujian pada penelitian ini yaitu dengan proses ECAP pada suhu $300^{\circ} \mathrm{C}$ dengan waktu tahan anil10, 15, dan 25 menityang meliputi Uji Kekerasan (metode Brinell) dan hasil pengamatan mikrostruktur.

\section{Hasil Pengujian Kekerasan}

Copyright $^{\circledR} 2018$ Jurnal Rekayasa Material, Manufaktur dan Energi. This is an open acces article under the CC-BY-SA lisence (https://creativecommons.org/licenses/by-sa/4.0/). 


\section{Published September 2018 \\ Jurnal Rekayasa Material, Manufaktur dan Energi http://jurnal.umsu.ac.id/index.php/RMME}

Pengujian kekerasan dilakukan menggunakan standart pengujian E10-01. Pengujian kekerasan ini dilakukan terhadap sampel aluminium silikon menggunakan metode pengujian Brinell dengan beban sebesar $500 \mathrm{~kg}$ selama 5 detik. Foto sampel uji kekerasan dan pengambilan sampel uji dilakukan pada 3 titik bagian, dapat dilihat pada gambar 3.

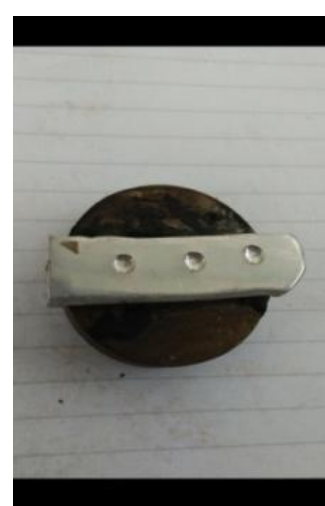

Gambar 3.Spesimen yang diuji kekerasannya pada 3 titik bagian.

Setelah dilakukan pengujian spesimen menggunakan metode Brinell maka diperoleh hasil kekerasan seperti yang diperlihatkan pada tabel 1.

Tabel 1. Waktu tahan anil (menit) VS Hasil rata-rata uji kekerasan BHN dan Raw materialpada aluminium silikon:

\begin{tabular}{cccc}
\hline No & $\begin{array}{c}\text { Waktu tahan anil } \\
(\text { menit })\end{array}$ & $\begin{array}{c}\text { Kekerasan rata-rata pada suhu } \\
300^{\circ} \mathrm{C}\end{array}$ & Raw material \\
\hline 1 & 10 & 54,94 & 42,51 \\
2 & 10 & 54,96 & 42,51 \\
3 & 10 & 53,03 & 42,51 \\
\hline Rata-Rata & & 54,30 & 42,51 \\
\hline 4 & 15 & 51,20 & 42,51 \\
5 & 15 & 57,02 & 42,51 \\
6 & 15 & 57,02 & 42,51 \\
\hline Rata-Rata & & 55,08 & 42,51 \\
\hline 7 & 25 & 53,03 & 42,51 \\
8 & 25 & 57,02 & 42,51 \\
\hline
\end{tabular}


Published September 2018

\section{Jurnal Rekayasa Material, Manufaktur dan Energi} http://jurnal.umsu.ac.id/index.php/RMME

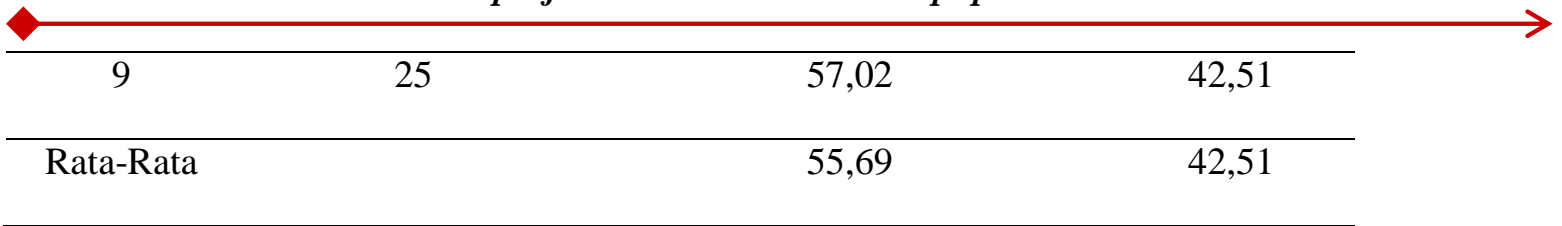

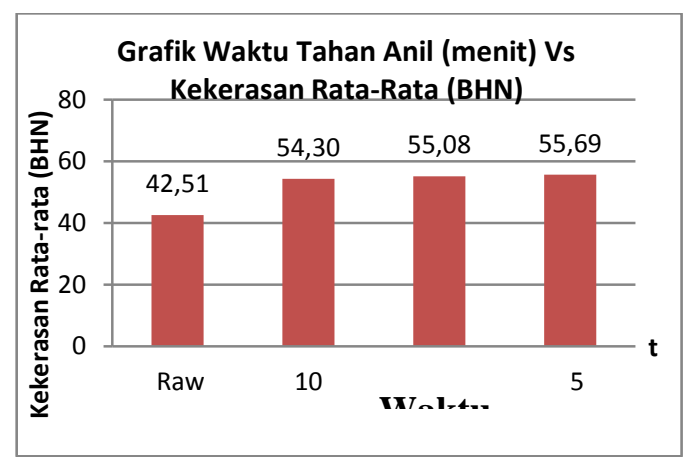

Gambar 4. Grafik Waktu tahan anil (menit) Vs Kekerasan.

Dari grafik diatas dapat disimpulkan bahwa pengaruh proses anil dan proses ECAP pada aluminium silikondengan suhu $300^{\circ} \mathrm{C}$ dapat meningkatkan nilai kekerasan $\mathrm{BHN}$ yaitu terlihat pada waktu tahan anil 10 menit nilai kekerasannya 54,30 BHN, sedangkan pada waktu tahan anil 15 menit nilai kekerasannya naik menjadi 55,08 BHNbegitu juga pada waktu tahan anil 25 menit nilai kekerasannyanaik tidak terlalu jauh menjadi 55,69 BHN dengan nilai kekerasan raw material 42,51 BHN.Disini dapat disimpulkan bahwa proses anil dan proses ECAP pada aluminium silikon dengan waktu tahan anil 10 menit, 15 menit dan 25 menit pada suhu $300^{\circ} \mathrm{C}$ dapat meningkatkan nilai kekerasan BHN secara meratadan pengaruh anil pada struktur mikro dengan waktu tahan anil 10 menit tidak terlalu jauh perbedaan struktur mikronya dibandingkan pada waktu tahan anil 15 dan 25 menit.

Sesuai dengan penelitian Kuswarini, Fakultas Teknik Universitas Indonesia tahun 2012, yaitu proses anil yang lebih tinggi pada spesimen dapat meningkatkan ukuran butir yaitu sama dengan menurunkan nilai kekerasan pada spesimen. Tetapi pada penelitian ini spesimen dianil kemudian diECAP, ketika dianil spesimen mengalami penurunan nilai kekerasan tetapi setelah diECAP ukuran butir pada spesimen tersebut kembali halus dan menaikkan nilai kekerasan pada spesimen aluminium silikon tersebut.

\section{Hasil Pengamatan Metallografi}

Pengamatan metallografi dilakukan pada sampel uji menggunakan mikroskop optik dengan 100x pembesaran. Pengamatan metallografi dilakukan untuk mengetahui struktur-struktur mikro raw material pada aluminium dan struktur mikro pada aluminium yang sudah dianil dan di ECAP.

Gambar 4. diatas memperlihatkan hasil pengamatan struktur mikro raw material pada permukaan aluminium silikon terdapat goresan-goresan garis yaitu disebabkan oleh proses poleshing yang kurang bagus atau bekas pengamplasan yang kurang bagus sehingga terlihat garisgaris pada permukaan aluminium silikon dengan menggunakan mikroskop optik pada 100x pembesaran. Struktur mikro pada raw material ini terlihat tidak beraturan struktur butir-butirnya, pada uji komposisi aluminium silikon ini menunjukkan bahwa kandungan silikonnya adalah 0,76 $\%$ sedangkan kandungan aluminiumnya 97,0\%. 


\title{
Published September 2018 \\ Jurnal Rekayasa Material, Manufaktur dan Energi http://jurnal.umsu.ac.id/index.php/RMME
}

\begin{abstract}
Pada spesimen yang telah di ECAP dan dianil pada waktu tahan 10 menit (terlihat pada gambar 4.5) struktur mikronya mulai terbentuk butir-butirdipermukaan aluminium silikonnya dibandingkan dengan struktur pada raw material.Spesimen yang telah di ECAP dan dianil dengan waktu tahan 15 menit (terlihat pada gambar 4.6)struktur mikronya terlihat lebih halus dibandingkan dengan spesimen yang dianil pada waktu tahan 10 menit disebabkan oleh proses waktu tahan anil yang lebih lama kemudian di ECAP. Hasil pengujian mikro ini memperlihatkan permukaan Aluminium Silikon berwarna gelap dengan banyak bagian dari Aluminium yang berwarna hitam yang merupakan Silikon Aluminium yang sejumlah besar silikon akan menghasilkan warna abu-abu yang gelap.

Dan selanjutnya pada spesimen yang telah di ECAP dan dianil pada waktu tahan 25 menit (terlihat pada gambar 4.7) butir terlihat lebih halus lagi dan lebih padat dibandingkan dengan butir pada waktu tahan anil 15 menitdisebabkan oleh waktu tahan anilnya yang lebih lama.Dapat diambil kesimpulan dari ketiga mikro struktur diatas semakin lama waktu tahan anil pada aluminium silikon dan di ECAP maka semakin halus struktur mikronya. Menurut Van der walls (dalam aditya dkk 2011) semakin dekat butir-butir didalam suatu material maka sifat kekerasan material tersebut semakin meningkat.
\end{abstract}

\section{KESIMPULAN DAN SARAN}

\section{Kesimpulan}

Dari hasil penelitian ini dapat disimpulkan :

Bahwa nilai kekerasan aluminium silikon hasil prosesanil dan proses ECAP meningkat dengan nilai kekerasan terbaik 55,69 BHN pada waktu tahan anil 25 menit.

Struktur mikro aluminium silikon hasil proses anil dan proses ECAP semakin halus butir-butirnya dengan waktu tahan anil terbaik 25 menit dibandingkan dengan waktu tahan anil 10 dan 15 menit.

\section{Saran}

Adapun saran pada penelitian ini adalah :

Perlu dilakukan penelitian lanjutan untuk mengetahui kekerasan pada penampang melintang hasil proses ECAP dan proses anil.

Perlu dilakukan penelitian ECAP untuk mengetahui pengaruhnya terhadap sifat atau karakteristik bahan yang lain.

\section{DAFTAR PUSTAKA}

[1] Olejnik dan Rosochowski, Material yang berukuran tinggi mampu bentuk yang tinggi tahan korosi dan komposisi kimia yang sederhana, 2005.

[2] Kuswarini, Penghalusan butir material kuningan melalui proses equal channel angular pressing dengan sudut cetakan $120^{\circ}$. Fakultas Teknik. Universitas Indonesia, 2012.

[3] Nugroho Eko, Pengaruh Unsur Aluminium Dalam Kuningan Terhadap Kekerasan, Kekuatan Tarik, dan Struktur Mikro. Fakultas Teknik. Universitas Muhammad Metro, 2011.

[4] Szajnar dan Wrobel, Peningkatan sifat mekanis aluminium diantaranya dengan penambahan paduan Ti-B untuk penghalusan butir, 2007. 


\section{Published September 2018 \\ Jurnal Rekayasa Material, Manufaktur dan Energi http://jurnal.umsu.ac.id/index.php/RMME}

[5] Goni dan Equizabal, AlSi8Cu3Fe dengan menambahkan $0,6 \% \mathrm{TiB}_{2}$ pada proses $\mathrm{HPDC}$, 2004.

[6] Kashyap, K.T. dan Chandrashekar, T. Effect and mechanisms of grain refinement in aluminium alloys, Bullet Mater Sci, Vol.4 no.4 August. 2001.

[7] Ginting, Penguatan Dengan Penghalusan Butir Pada Paduan Hipoeutektik Al-Si, Buletin IPT NO. III, 1998.

ASM International, Diagram fasa Al-Si, 2004.

ASM International, Kandungan Si terhadap temperatur titik beku paduan aluminium, 2004.

Considin P.E. Douglas M, Sifat-sifat fisik aluminium, 1983.

Van Der Walls, Semakin dekat butir-butir di dalam suatu material maka sifat kekerasan material tersebut semakin meningkat, dalam aditya dkk 2011. 